\title{
A close phylogenetic relationship between Sipuncula and Annelida evidenced from the complete mitochondrial genome sequence of Phascolosoma esculenta
} Xin Shen ${ }^{*} 1,2$, Xiaoyin Ma ${ }^{\dagger 3}$, Jianfeng Ren $^{2}$ and Fangqing Zhao*4

Address: ${ }^{1}$ Jiangsu Key Laboratory of Marine Biotechnology/College of Marine Science, Huaihai Institute of Technology, Lianyungang 222005, PR China, ${ }^{2}$ Institute of Oceanology, Chinese Academy of Sciences, Qingdao 266071, PR China, ${ }^{3}$ Wenzhou Medical College, Wenzhou 325035, PR China and ${ }^{4}$ Department of Biochemistry and Molecular Biology, Pennsylvania State University, Pennsylvania 16802, USA

Email: Xin Shen* - shenthin@163.com; Xiaoyin Ma - mxy082002@yahoo.com.cn; Jianfeng Ren - rjf98yy@yahoo.com.cn; Fangqing Zhao* - fuz3@psu.edu

* Corresponding authors †Equal contributors

Published: 28 March 2009

BMC Genomics 2009, 10:136 doi:10.1186/147|-2164-10-136
Received: 8 September 2008

Accepted: 28 March 2009

This article is available from: http://www.biomedcentral.com/I47I-2/64/I0/I36

(C) 2009 Shen et al; licensee BioMed Central Ltd.

This is an Open Access article distributed under the terms of the Creative Commons Attribution License (http://creativecommons.org/licenses/by/2.0), which permits unrestricted use, distribution, and reproduction in any medium, provided the original work is properly cited.

\begin{abstract}
Background: There are many advantages to the application of complete mitochondrial $(\mathrm{mt})$ genomes in the accurate reconstruction of phylogenetic relationships in Metazoa. Although over one thousand metazoan genomes have been sequenced, the taxonomic sampling is highly biased, left with many phyla without a single representative of complete mitochondrial genome. Sipuncula (peanut worms or star worms) is a small taxon of worm-like marine organisms with an uncertain phylogenetic position. In this report, we present the mitochondrial genome sequence of Phascolosoma esculenta, the first complete mitochondrial genome of the phylum.

Results: The mitochondrial genome of P.esculenta is 15,494 bp in length. The coding strand consists of $32.1 \%$ A, $21.5 \%$ C, $13.0 \%$ G, and 33.4\% T bases (AT = 65.5\%; AT skew = -0.019 ; GC skew $=-0.248$ ). It contains thirteen protein-coding genes (PCGs) with 3,709 codons in total, twenty-two transfer RNA genes, two ribosomal RNA genes and a non-coding AT-rich region (AT $=74.2 \%$ ). All of the 37 identified genes are transcribed from the same DNA strand. Compared with the typical set of metazoan $\mathrm{mt}$ genomes, sipunculid lacks trnR but has an additional trnM. Maximum Likelihood and Bayesian analyses of the protein sequences show that Myzostomida, Sipuncula and Annelida (including echiurans and pogonophorans) form a monophyletic group, which supports a closer relationship between Sipuncula and Annelida than with Mollusca, Brachiopoda, and some other lophotrochozoan groups.
\end{abstract}

Conclusion: This is the first report of a complete mitochondrial genome as a representative within the phylum Sipuncula. It shares many more similar features with the four known annelid and one echiuran mtDNAs. Firstly, sipunculans and annelids share quite similar gene order in the mitochondrial genome, with all 37 genes located on the same strand; secondly, phylogenetic analyses based on the concatenated protein sequences also strongly support the sipunculan + annelid clade (including echiurans and pogonophorans). Hence annelid "key-characters" including segmentation may be more labile than previously assumed. 


\section{Background}

Sipunculans (peanut worms or star worms) form a minor phylum of nonsegmented coelomate worms with bilaterally symmetrical bodies that are divisible into a trunk and a retractable introvert. In spite of low species diversity (about 150 species), sipunculans are found from tropical to Antarctic oceans [1,2]. The fossil records for sipunculans are generally rare but three species from the Lower Cambrian Maotianshan Shale were reported by Huang et al. (2004), suggesting that the most typical features of extant sipunculans have undergone only minor changes over the past 520 million years [3]. Although the group was first documented in 1555, their phylogenetic relations are controversial $[1,4,5]$. In 1767 Linnaeus described Sipunculus nudus, placing it within the Vermes Intestina, a group containing truly "internal worms" and other bilateral invertebrates lacking lateral appendages [6]. These were later considered to be a derived group of annelids [7]. Quatrefages (1847) proposed the name Gephyrea or "bridge group" for sipunculans, echiurans and priapulids, assuming that they represented a connection between annelids and echinoderms [8]. Hyman (1959) suggested the disposal of Gephyre on the grounds that it was simply an easy way of grouping organisms of uncertain phylogenetic affinities. Furthermore, she suggested the elevation of sipunculans to phylum status (under the name Sipunculida) [5]. Later on, Stephen (1965) proposed the name Sipuncula for the phylum [9], a term which has been widely adopted.

Scheltema (1993) maintained the presence of a molluscan-cross during cleavage as an indication to place Sipuncula as the sister taxon to the Mollusca [10]. However, cell lineage studies have shown that the concept of the molluscan-cross vs. the annelidan-cross is oversimplified and of limited phylogenetic significance [11]. Due to superficial body plan similarity, sipunculans and echiurans are often grouped together [12]. But prominent differences including anal position and proboscis form suggest that the similar body plans are a result of convergence due to parallel burrowing lifestyles, rather than common ancestry. Recently, the Echiura has been considered a derived polychaete group that may have lost segmentation $[13,14]$, leading to a more confused placement of sipunculans.

Previous cladistic analyses based on morphological and limited molecular data have rendered a great variety of hypotheses relating Sipuncula, including sister group to Echiura [15], sister group to Annelida [16], sister group to Mollusca [10], sister group to Echiura + Annelida [17], sister group to Mollusca + Annelida [18], and sister group to an unresolved clade containing Mollusca, Annelida and the Panarthropoda [19], or within Annelida [4]. In sum- mary, little agreement is reached with regards to the exact position of Sipuncula within the protostomes.

With a few remarkable exceptions, animal mitochondrial DNAs (mtDNAs) are circular molecules, $14-20 \mathrm{~kb}$ in size, containing 37 genes: 13 for proteins of electron transport (cox1-3, cob, nad1-6, nad4L, atp6 and atp8), 2 for ribosomal RNAs (srRNA and IrRNA), and 22 for transfer RNAs. Over the past decades, inference of a deeper phylogenetic relationship of Metazoa with complete mitochondrial genome sequences has gained popularity [20-22]. This resulted from many advantages offered over other molecular markers for phylogenetic analysis, such as (a) ease of isolation and assaying; (b) simple genetic structure lacking complicated features such as repetitive DNA, transposable elements, pseudogenes, and introns; and (c) effectively single copy, comparison of paralogous genes is generally not a concern [21]. In addition, mitochondrial genome provides a systematic view and measurement of evolutionary history of an organism which is synchronized with the nuclear genome of the host [23]. More importantly, compared to individual genes, mitochondrial genomes can provide sets of genome-level characteristics, such as the relative rearrangements of gene orders, which can be powerful for phylogenetic analysis [24,25].

More than one thousand complete mitochondrial genome sequences http://www.ncbi.nlm.nih.gov/ genomes/ORGANELLES/mztax_short.html have been reported to date. The taxonomic sampling, however, is highly biased toward vertebrates and arthropods (both groups account for $\sim 86 \%$ of sequenced $\mathrm{mt}$ genomes), with no complete $\mathrm{mt}$ genome in many minor phyla. Minor phyla are generally considered to be of little consequence usually with uncertain affinity in mainstream animal evolution theories because they are not well represented in present macrofauna. However, if we use the questionable definition of a phylum as a taxon with a distinctly unique body plan and leave aside the requirement of monophyly, then minor phyla represent the majority of nature's experimentation with animal body plans [26].

In this paper, we described the gene content, organization and codon usage of the first complete mitochondrial genome in the phylum Sipuncula, Phascolosoma esculenta. We analyzed the phylogentic relationship of Sipuncula with mitochondrial genomes from Annelida, Echiura, Pogonophora, Myzostomida, Mollusca and some other protostomes. The result provides further evidence on phylogenomic scale to a close relationship of Myzostomida, Sipuncula and Annelida (including echiurans and pogonophorans). 


\section{Results and Discussion General features}

The mitochondrial genome of $P$. esculenta is $15,494 \mathrm{bp}$ in length, and encodes a set of 37 metazoan genes (thirteen protein-coding, two ribosomal RNA, and twenty-two transfer RNA genes) (Figure 1; Table 1). The overall A+T content of P.esculenta (65.5\%) is higher than that of the mitochondrial genomes from the Annelida/Echiura group except for one polychaete Clymenella torquata (67.2\%) [see additional file 1]. The entire P.esculenta mtDNA sequence has been deposited in GenBank with accession number EF583817.

\section{Gene order}

All the mitochondrial genes of P.esculenta are transcribed from the same strand (Figure 1), as is the case for the four studied annelids (Orbinia latreillii [27], C.torquata [28], Platynereis dumerilii [29], and Lumbricus terrestris [20]), one echiuran Urechis caupo [30], and many other lophotrochozoan mtDNAs [31]. There may be an evolutionary "ratchet" in cases where all genes coincidentally occur on the same strand that is caused by the loss of the transcriptional signals for the opposite strand, which then makes further inversions lethal [31]. The gene synteny in P. esculenta shares moderate similarity with other four annelid mtDNAs (Figure 2).

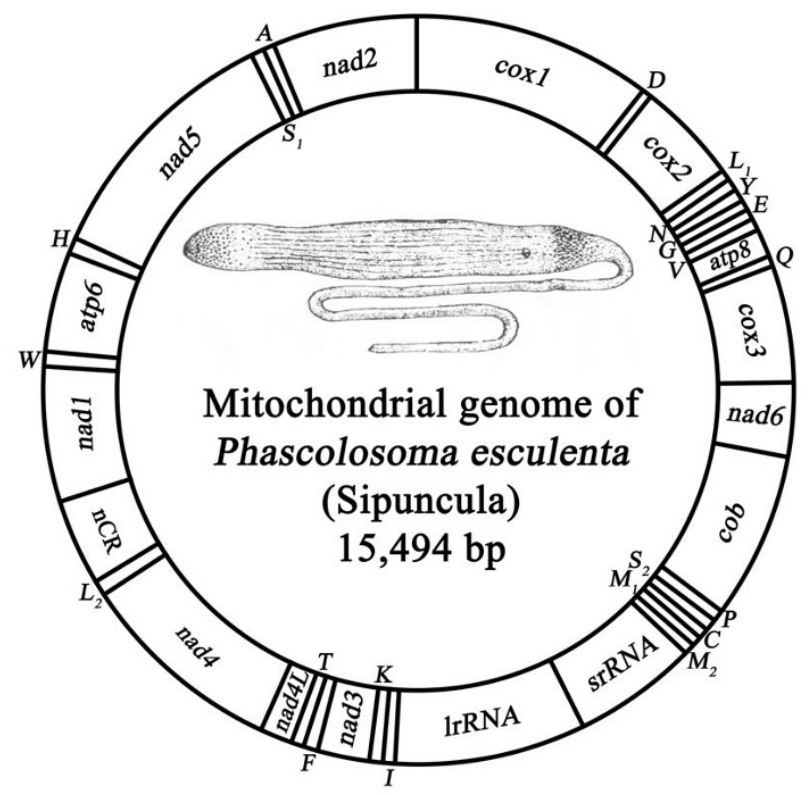

Figure I

Gene map of mitochondrial genome of the $P$. esculenta (Sipuncula: Phascolosomatidea). All thirteen protein-coding, two ribosomal RNA and twenty-two transfer RNA genes are encoded on the same strand. Transfer RNA genes are designated by single-letter amino acid codes.
The gene order in annelids is quite conserved with the exception of just a few tRNA genes. Comparing all the known annelid mitochondrial genomes, six conserved gene clusters can be found: (1) $\operatorname{cox} 1-\mathrm{N}-\cos 2$; (2) $\operatorname{cox} 3-\mathrm{Q}-$ nad6-cob-W-atp6-R; (3) H-nad5-F-E-P-T-nad4L-nad4; (4) srRNA-V-lrRNA; (5) nad1-I; and (6) nad3-S $S_{1}$-nad2 (Figure 2). U.caupo (Echiura) contains four of them compared with annelids, including (1)Q-nad6-cob-W-atp6- $R$; (2)Hnad5-F; (3)T-nad4L-nad4; and (4) nad1-I. In comparison with the four annelids, three conserved gene clusters are present in P.esculenta, including (1)nad6-cob; (2)T-nad4Lnad4; and (3)W-atp6 (Figure 2). As to the partial mitochondrial genome of a sipunculid Phascolopsis gouldii [32], it also possesses three conserved regions ( $\operatorname{cox} 1-\mathrm{N}-\operatorname{cox} 2$, cox3-Q-nad6-cob, and srRNA-V-lrRNA), and it is surprising that the first and third gene blocks located in the P.gouldii cannot be found in the mitochondrial genomes of $U$. caupo or P.esculenta (Figure 2). Meanwhile, gene order in the mitochondrial genomes of Riftia pachyptila (Pogonophora) and Myzostoma seymourcollegiorum (Myzostomida) also showed remarkable similarities with studied annelids [28,33].

A conserved pattern of gene order across sipunculans, echiurids, pogonophorans, myzostomids, and annelids was surprising, since high variations in gene order is known to occur within closely related taxa like brachiopods [34-36] and molluscs [37-39]. Jennings and Halanych (2005) suggested that gene order data are of limited utility in Annelida [28]. On the contrary, Bleidorn et al. (2006) believed that such data may be a promising tool to search for synapomorphic gene rearrangements and shed light on annelid related phylogeny [27]. At this moment, it is still too early to say whether the gene order is a crucial tool or not, when complete mitochondrial genomes are still underrepresented for annelid related groups. However, from known data it can be concluded that gene rearrangements in this group may be less frequent than in other lophotrochozoan taxa, although more frequent than previously thought.

\section{Protein-coding genes}

Mitochondrial genes commonly use several alternatives to ATG as start codons. Ten of the thirteen PCGs (atp6, atp8, cob, cox2, nad1-3, nad4L and nad5-6) of P.esculenta initiate with the ATG start codon, while cox3 and nad4 genes start with ATA and the cox1 gene with the TTG codon (Table 1). Nine open-reading frames end with the TAA stop codon (atp6, atp8, cox1-3, nad1, nad4L, nad5 and nad6), and the remaining ones (cob, nad2, nad3 and nad4) have incomplete stop codons. Such immature stop codons are common among animal mitochondrial genomes, and it has been shown that TAA stop codons are created via posttranscriptional polyadenylation [40]. 
Table I: Mitochondrial gene profile of the $P$. esculenta

\begin{tabular}{|c|c|c|c|c|c|}
\hline \multirow[t]{2}{*}{ Genes and features } & \multirow{2}{*}{$\begin{array}{l}\text { Positions } \\
\text { From to }\end{array}$} & \multirow[t]{2}{*}{ Size (bp) } & \multicolumn{2}{|c|}{ Codon } & \multirow[t]{2}{*}{ Intergenic Nucleotides* } \\
\hline & & & Start & Stop & \\
\hline $\operatorname{cox} I$ & $1-1560$ & 1560 & TTG & TAA & 2 \\
\hline $\operatorname{trn} D$ & $1563-1628$ & 66 & & & 40 \\
\hline $\operatorname{cox} 2$ & $1669-2364$ & 696 & ATG & TAA & 10 \\
\hline $\operatorname{trn} L_{1}$ & $2375-2436$ & 62 & & & I \\
\hline $\operatorname{trnN}$ & $2438-2506$ & 69 & & & 0 \\
\hline $\operatorname{trn} Y$ & $2507-2578$ & 72 & & & -1 \\
\hline $\operatorname{trn} E$ & $2578-2645$ & 68 & & & -3 \\
\hline $\operatorname{trnG}$ & $2643-2708$ & 66 & & & 3 \\
\hline $\operatorname{trn} V$ & $27 \mid 2-2774$ & 63 & & & 13 \\
\hline atp8 & $2788-2952$ & 165 & ATG & TAA & 6 \\
\hline $\operatorname{trn} Q$ & $2959-3026$ & 68 & & & 106 \\
\hline $\operatorname{cox} 3$ & $3133-3936$ & 804 & ATA & TAA & 4 \\
\hline nad6 & $394|-44| 4$ & 474 & ATG & TAA & 2 \\
\hline$c o b$ & $4417-5552$ & 1136 & ATG & $\mathrm{T}-$ & 0 \\
\hline $\operatorname{trn} P$ & $5553-5617$ & 65 & & & -1 \\
\hline $\operatorname{trnS} S_{2}$ & $56 \mid 7-5683$ & 67 & & & -1 \\
\hline $\operatorname{trnC}$ & $5683-5743$ & 61 & & & 2 \\
\hline $\operatorname{trn} M_{1}$ & $5746-5807$ & 62 & & & 0 \\
\hline $\operatorname{trn} M_{2}$ & $5808-5868$ & 61 & & & 0 \\
\hline srRNA & $5869-6706$ & 838 & & & 0 \\
\hline IrRNA & $6707-7981$ & 1275 & & & 0 \\
\hline trnl & $7982-8046$ & 65 & & & 0 \\
\hline $\operatorname{trnK}$ & $8047-8110$ & 64 & & & 0 \\
\hline nad3 & $8111-8474$ & 364 & ATG & T- & 0 \\
\hline trnK & $8475-8537$ & 63 & & & I \\
\hline $\operatorname{trn} T$ & $8539-8600$ & 62 & & & 1 \\
\hline $\operatorname{nad} 4 \mathrm{~L}$ & $8602-8886$ & 285 & ATG & TAA & -4 \\
\hline nad4 & $8883-10233$ & $|35|$ & ATA & $\mathrm{T}-$ & 0 \\
\hline $\operatorname{trnL}_{2}$ & $10234-10296$ & 63 & & & 0 \\
\hline $\mathrm{nCR}$ & $|0297-1088|$ & 585 & & & 0 \\
\hline nadl & $10882-11796$ & 915 & ATG & TAA & 2 \\
\hline $\operatorname{trnW}$ & $11799-1 \mid 860$ & 62 & & & 0 \\
\hline atp6 & $1|86|-12556$ & 696 & ATG & TAA & 63 \\
\hline $\operatorname{trnH}$ & $12620-12680$ & 61 & & & 0 \\
\hline nad5 & $|268|-\mid 4396$ & 1716 & ATG & TAA & 2 \\
\hline $\operatorname{trn} S_{1}$ & |4399-|4464 & 66 & & & 3 \\
\hline $\operatorname{trn} A$ & $|4468-| 4530$ & 63 & & & -6 \\
\hline nad2 & |4525-|5494 & 970 & ATG & T- & 0 \\
\hline
\end{tabular}

NOTE. * Numbers correspond to the nucleotides separating different genes. Negative numbers indicate overlapping nucleotides between adjacent genes.

"-" indicates termination codons completed via polyadenylation.

Among the thirteen PCGs, there is one reading-frame overlap between nad4L and nad4 genes (Table 1) [also see additional file 2]. We speculate that nad4L may have an abbreviated stop codon, but is inferred to overlap with nad4 by four nucleotides to the first legitimate stop codon, since overlap of this pair has been commonly observed in other mtDNAs $[27,30,41]$. It is not clear how gene overlaps could be resolved from a polycistronic transcript, but the presence of these stop codons seems beyond coincidence. It could be that they serve as a "back up" in case translation and should begin in the absence of transcript cleavage [30].

\section{Base composition and codon usage}

The coding strand in P.esculenta consists of $32.1 \% \mathrm{~A}$, $21.5 \% \mathrm{C}, 13.0 \% \mathrm{G}$, and $33.4 \% \mathrm{~T}$ bases [see additional file $3]$. The bias of the base composition of an individual strand can be described by skewness [42], which measures the relative numbers of As to Ts and Gs to $\mathrm{Cs}$ and is calculated as (A\%-T\%)/(A\%+T\%) and $(\mathrm{G} \%-\mathrm{C} \%) /(\mathrm{C} \%+\mathrm{G} \%)$, respectively. The PCGs have a strong skew of $\mathrm{C}$ vs. $\mathrm{G}$ ($0.191 \sim-0.456)$, except that the cox3 gene has a weaker skew of $\mathrm{C}$ vs. G (-0.083); whereas the AT skew is only slightly negative for most PCGs $(-0.003 \sim-0.243)$ except for the cox 2 and atp 8 genes (AT skew $=0.146$ and 0.069 in 


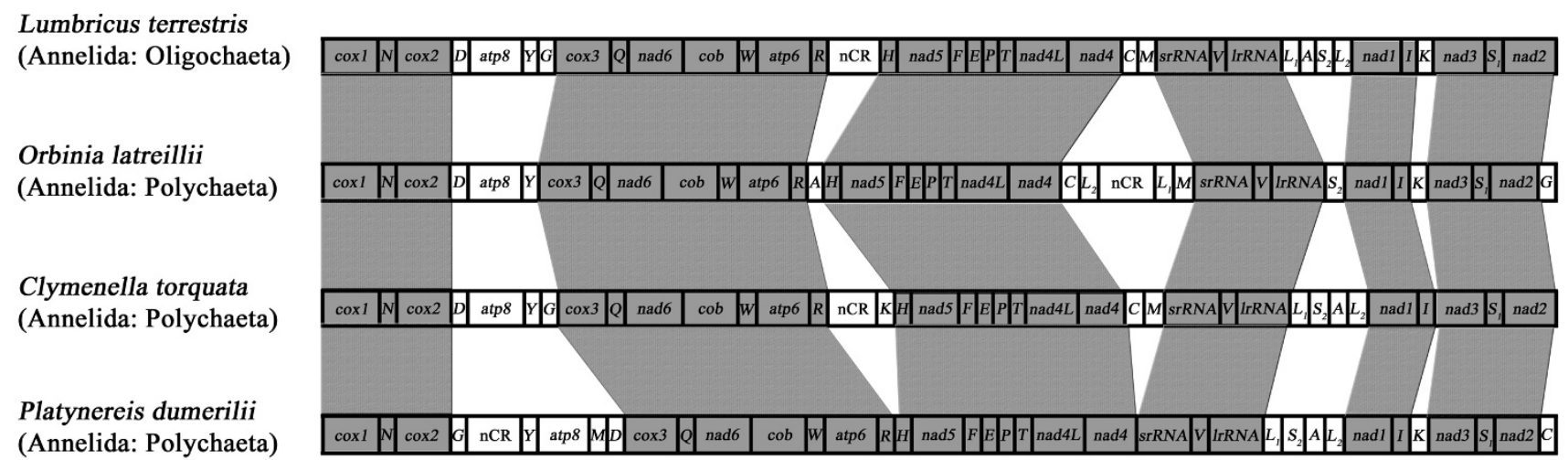

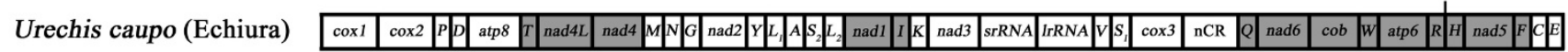

Phascolosoma esculenta (Sipuncula)

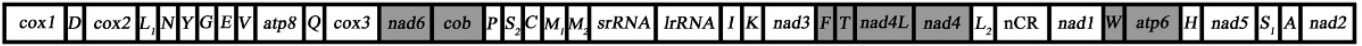

Phascolopsis gouldii (Sipuncula)

Katharina tunicata (Mollusca)

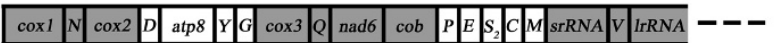

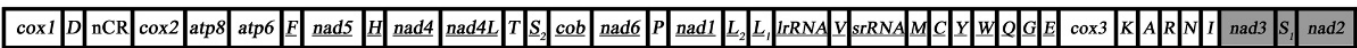

Figure 2

Gene orders of mitochondrial genomes from Sipuncula and the Annelida/Echiura group. Abbreviations are as explained in the text. Shaded boxes highlight different sets of conserved gene blocks among the taxa shown. Gene segments are not drawn to scale. All genes are transcribed from left-to-right except those indicated by underlining, which are transcribed from right to left.

cox 2 and atp8 genes, respectively). Base composition and skewness of PCGs are similar to the whole genome (AT = 65.5\%; AT skew = -0.019; GC skew = -0.248) [see additional file 3]. As can be seen in the additional file 4, this is strongly reflected in the use of synonymous codons. As for two rRNA genes, GC skew is weaker than that of the whole genome (GC skew $=-0.074$ and -0.190 for the srRNA and IrRNA genes, respectively), which perhaps because of the requirement for base pairing in the secondary structures of the products [43]. On the contrary, the AT skew displayed an opposite pattern to the whole genome and has a slightly skew of A vs. T (AT skew $=0.068$ and 0.053 for srRNA and $\operatorname{lrRNA}$ genes, respectively), which is consistent to four studied annelids except for U.caupo (AT skew = 0.015 for the whole genome of U.caupo) [see additional file 3].

The $\mathrm{A}+\mathrm{C}$ and $\mathrm{G}+\mathrm{T}$ frequency in protein-coding and ribosomal RNA genes of P.esculenta, U.caupo and the four studied annelids was calculated [see additional file 3], and the whole genome scanning of P.esculenta and U.caupo is shown in additional file 2. That the emergence of $\mathrm{A}+\mathrm{C}$ is more frequent than $\mathrm{G}+\mathrm{T}$ has shown in all the six mitochondrial genomes as a whole, and all thirteen PCGs and two rRNAs of U.caupo and O.latreillii displayed a similar pattern to the whole genome, which results in the highest $\mathrm{A}+\mathrm{C}$ frequency of the two species. On the contrary, the remaining four species have at least one gene that $\mathrm{G}+\mathrm{T}$ is more frequent than $\mathrm{A}+\mathrm{C}$ [see additional file 3].

The pattern of codon usage in the P.esculenta mtDNA was also studied [see additional file 4]. There are a total of 3,709 codons in all thirteen mitochondrial PCGs, excluding incomplete termination codons. The most frequently used amino acids were Leu $(17.69 \%)$, followed by Ser (9.65\%), Phe (8.95\%), Ile (7.74\%), and Ala (7.09\%). A common feature in most metazoan genomes is a bias towards a higher representation of nucleotides $\mathrm{A}$ and $\mathrm{T}$ which leads to a subsequent bias in the corresponding encoded amino acids. This result comes from the fact that the third codon positions of the PCGs in P.esculenta prefer $\mathrm{T}$ more than those in annelid and echiuran species. The 
overall AT composition of protein-coding regions is $64.9 \%$, but at the third codon positions the AT composition elevates to $78.2 \%$, which is higher than the average level among the mitochondrial genomes from the Annelida/Echiura group [see additional file 1].

\section{Transfer and Ribosomal RNA genes}

The P.esculenta mtDNA encodes 22 tRNA genes, each folding into a clover-leaf secondary structure (Figure 3 ) and ranging in size from $61\left(\operatorname{trn} C, \operatorname{trn} \mathrm{M}_{2}\right.$ and $\left.\operatorname{trn} H\right)$ to $72(\operatorname{trnY})$ nucleotides. There are five cases in total where tRNA genes appear to overlap by one to six nucleotides (Table 1). Compared with a standard set of metazoan mt genomes, the sipunculid mitochondrial genome lacks trnR and has an extra $\operatorname{trn} M$. The absence of tRNA gene(s) was found in some metazoan mitochondrial genomes $[44,45]$. Twenty two tRNA genes were identified on the basis of their respective anticodons and secondary structures. Gene sizes and anticodon nucleotides were congruent to those described for other metazoan species.

DOGMA [46] and BLAST analyses indicate that the srRNA and $\operatorname{lrRNA}$ genes are adjacent to the $\operatorname{trn} \mathrm{M}_{2}$ and $\operatorname{trnI}$ genes, and both of them are located on the coding strand. The rRNA gene boundaries were estimated from nucleotide sequence alignments with annelids species. The lengths of

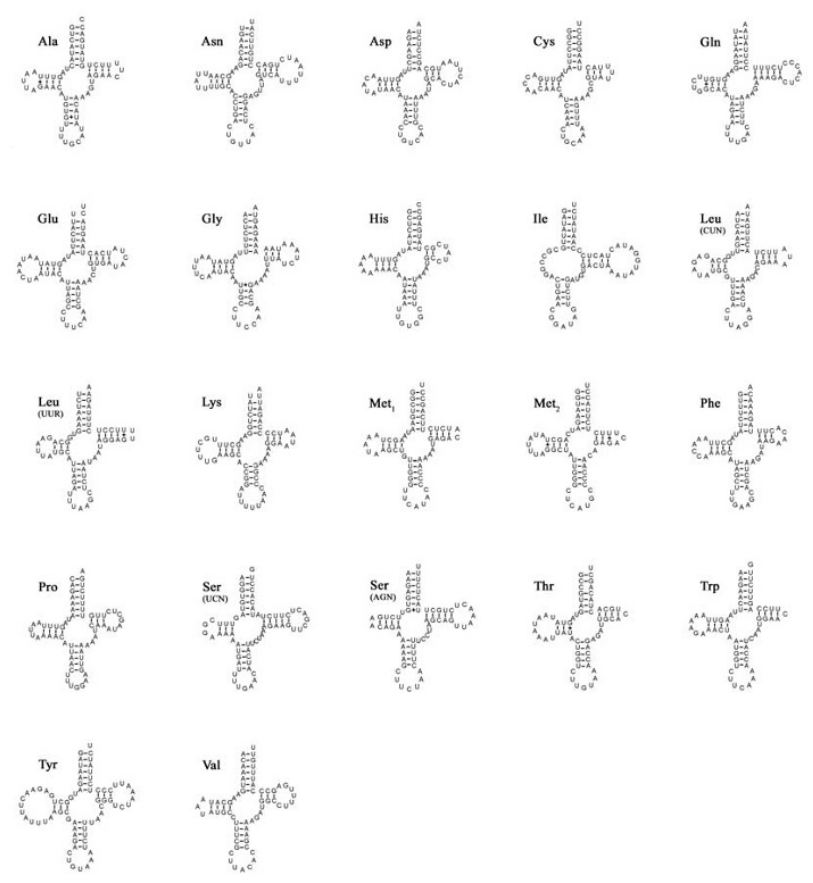

Figure 3

Putative secondary structures for 22 tRNA genes of the $P$. esculenta (Sipuncula: Phascolosomatidea). Watson-Crick and GT bonds are denoted by "-" and "+", respectively.
srRNA and lrRNA genes are 838 and $1,419 \mathrm{bp}$, and the $\mathrm{A}+\mathrm{T}$ contents are $63.7 \%$ and $65.8 \%$, respectively, which are higher than those of the mitochondrial genomes from the Annelida/Echiura group except for the C.torquata (65.4\% and $70.5 \%$ for $s r R N A$ and $l r R N A$ genes, respectively) [see additional file 1].

\section{Unassigned Sequence}

In the mitochondrial genome of the P.esculenta, a total of 846 bp of non-coding nucleotides are scattered among eighteen intergenic regions, including a single region of $585 \mathrm{bp}$. The largest non-coding region between the $\operatorname{trn} L_{2}$ and nad 1 is suggestive of a putative control region based on its high $\mathrm{A}+\mathrm{T}$ content (AT $=74.2 \%$ ) (Figure 1 ) [see additional file 1]. Except for the largest non-coding region, there are also three large intergenic regions adjacent to trnQ and cox3, atp6 and trnH, and trnD and $\operatorname{cox} 2(106,63$ and $40 \mathrm{bp}$ in length, respectively), and others have 1 to 13 bp in length (Table 1). Tandem repeats of CAAA and TA are common in four larger intergenic regions with 16 (CAAA)s and 106 (TA)s, and an especially noteworthy $(\mathrm{TA})_{10}$ was found in the largest region between the $\operatorname{trn} L_{2}$ and nad1.

\section{Phylogenomic relationship}

Phylogenies based on Maximum Likelihood (ML) and Bayesian analyses of the concatenated protein sequences were in almost complete agreement (Figure 4). In both cases, Sipuncula and Annelida (including echiurans and pogonophorans) form a monophyletic group $(\mathrm{BPP}=100$, BPM $=98$ ), which strongly supports a closer relationship between Sipuncula and Annelida than with Mollusca, Brachiopoda, and some other lophotrochozoan groups. Gene arrangement comparisons are a powerful tool for phylogenetic studies, especially for the estimation of ancient relationships [25]. A survey of mitochondrial gene order revealed a great conservation of gene arrangements across sipunculans, annelids and echiurids [see additional file 5]. Both gene arrangement data and inferred amino acid sequences reveal that the sipunculan should be consistently and significantly clustered with annelids to the exclusion of molluscs and other taxa. Our findings are in general agreement with several published molecular studies, which grouped sipunculans with annelids closely $[4,18,32,47-49]$. Comparative morphological and embryological evidence provide an additional support for such relationship between Sipuncula and Annelida. Investigation of larval ocelli in pelagosphera larvae gave evidence for an annelid affinity rather than to molluscs [50]. This evidence is consistent with a morphological study of neural and muscle formation in the sipunculan Phascolion strombus [51]. A recent research on the neural patterning of Phascolosoma agassizii revealed sipunculan neurogenesis initially follows a segmental pattern similar to that of annelids, which suggests the segmental ancestry of Sipun- 
cula [49]. If sipunculans did evolve from segmented worms, then their body plan must have changed extensively at or before the start of the Cambrian, followed by a remarkable period of stasis for the past half billion years [3]. The absence of segmentation in Sipuncula would then be a secondary loss [49], probably associated with the exploitation of a sedentary, burrowing lifestyle [52].

The hypothesis that echiurans are derived annelids was supported by our analyses (Figure 4), which is in consen- sus with several previous studies $[13,14,53,54]$. The metameric organisations of the nervous system found in $U$. caupo and Bonellia viridis are thus interpreted as an indication that echiurans are derived from a segmented ancestor [14], and the lack of segmentation in adult echiurans is therefore regarded as secondary [55]. However, the lack of segmentation in Echiura has been the single most important reason for excluding the group from the Annelida. Considering the support provided by these results for the theory that the lack of segmentation in adult echiurans is

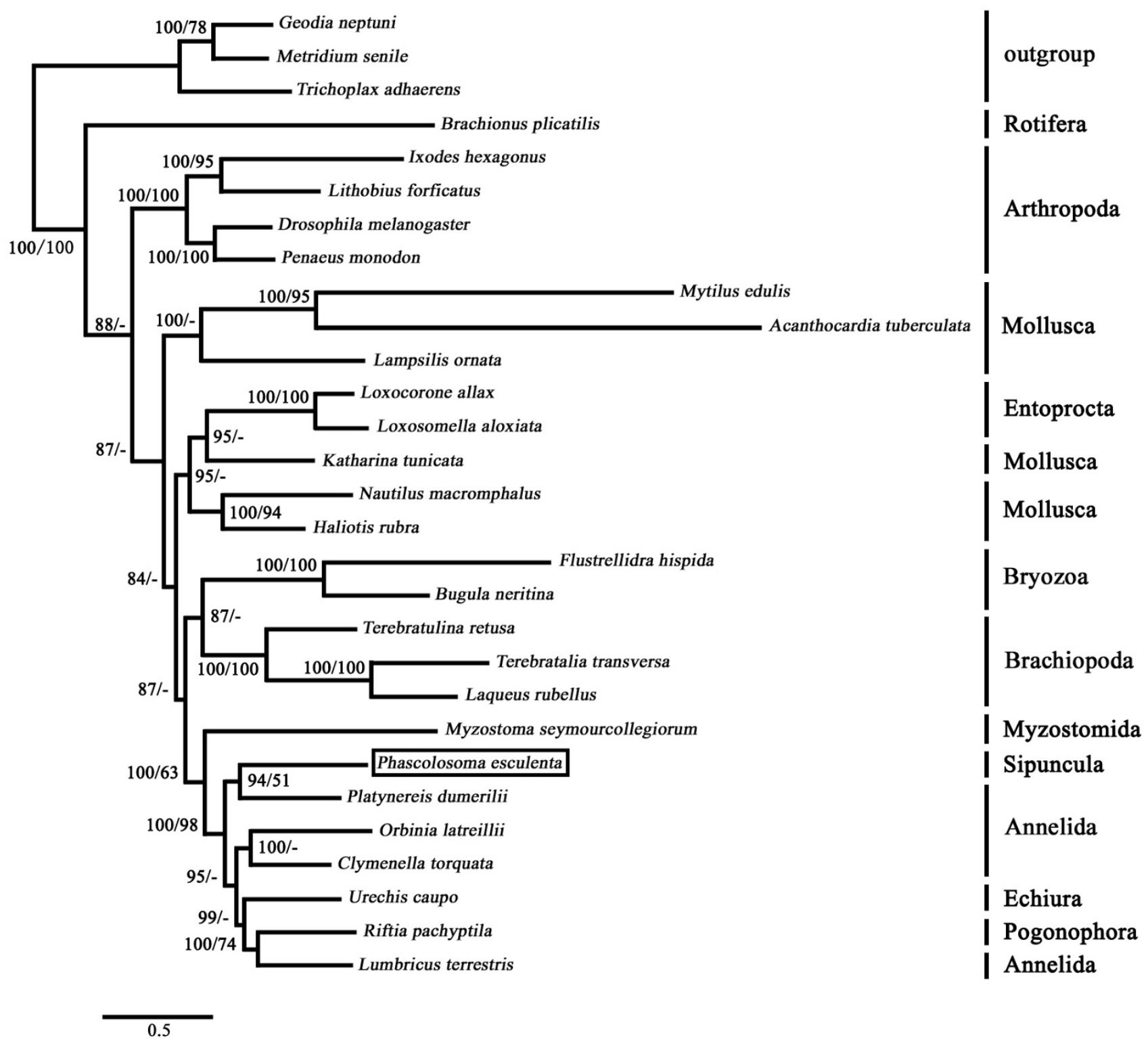

\section{Figure 4}

Phylogenetic tree based on seven concatenated mitochondrial PCGs. Tree topologies produced by the two methods were very similar. Only bootstrap values or posterior probabilities more than $50 \%$ are shown and the others are represented by "-". The first numbers are from Bayesian inferences (BPP) and the second numbers are from maximum likelihood analyses (BPM). The root of all trees was determined by using the data from Porifera, Cnidaria, and Placozoa species as the outgroup. 
the result of reduction, it can be concluded that Echiura share the same fundamental characters that are currently regarded to constitute the bauplan of Annelida. The segmental organisation of the nervous system in combination with the numerous additional characters shared by echiurans and annelids, therefore, support a phylogenetic classification of Echiura as a subtaxon of Annelida [55].

The phylogenetic analyses based on mitochondrial genomes also confirmed the fact that pogonophorans are derived annelids (Figure 4). Pogonophorans nested within the annelids was proved by both molecular and morphological cladistic analyses $[13,28,29,56]$. Given the name Pogonophora is misleading at this level, McHugh proposed the name of the group reverted to that of the first family group name originally formulated for members of the group, that of Siboglinidae Caullery, 1914 [13].

The annelid affinity of myzostomids has been challenged in recent times [48]. However, Bleidorn et al. (2007) assumed that myzostomids are part of the annelid radiation based on data from nuclear genes and mitochondrial genomes [33]. Here, the phylogenetic analyses based on mitochondrial genomes confirmed a close relationship between myzostomids and sipunculans+annelids clade (including echiurans and pogonophorans) (Figure 4), which is in agreement with the morphological evidence that myzostomids are part of the annelid radiation $[56,57]$.

Fundamentally different animal body plans, or phyla, constitute groups that are assumed to maintain their phylogenetic integrity as far back as they can be traced [13]. The great expansion of molecular data sets and improvements in phylogenetic methods have drastically changed our understanding of body plan evolution. Traditional key characteristics such as segmentation, radial versus spiral cell cleavage patterns in early embryogenesis, and modes of coelom formation appear to be more plastic and less reliable as phylogenetic characters than previously thought. Segmentation has traditionally been used as the basis for uniting annelids and arthropods as sister taxa [53], and the alternative hypothesis supports a sister relationship between molluscs and annelids, with the exclusion of arthropods, on the basis of the trochophore larva (the Ecdysozoa/Lophotrochozoa hypothesis) [58]. The placement of unsegmented Echiura and Sipuncula within Annelida radiation implies that segmentation is secondarily lost multiple times. If unsegmented echiurans are modified annelids and do not represent the unique body plan, then segmentation is an evolutionarily labile body plan character that has been lost rather than never gained by them [13].

\section{Conclusion}

This is the first report of a complete mitochondrial genome of a representative within the phylum Sipuncula. Many features aresimilar to four studied annelids and one echiuran mtDNAs. As in case of these five and many other lophotrochozoan mtDNAs, all 37 genes are transcribed from the same DNA strand. Three conserved gene blocks compared with the four studied annelids can be identified in the P.esculenta, including (1) nad6-cob; (2) T-nad4Lnad4; and (3) W-atp6. Phylogenetic analyses based on inferred amino acids shown that Myzostomida, Sipuncula and Annelida (including echiurans and pogonophorans) form a monophyletic group, which supports a closer relationship between Sipuncula and Annelida than with Mollusca, Brachiopoda and some other lophotrochozoan groups. Thus, many characteristics that have been hypothesized to link sipunculans with molluscs, including their developmental pattern and lack of segmentation, should be reevaluated.

\section{Methods}

\section{Sample collection and DNA extraction}

Live specimen of the P.esculenta was obtained from the Wenling breeding farm (Zhejiang province, China). The muscle tissues were excised and immediately preserved at $-80^{\circ} \mathrm{C}$. Total genomic DNA was extracted from the tissues using a DNeasy tissue DNA extraction kit (Promega) following the manufacturer's instructions, and was dissolved in TE buffer.

\section{$P C R$ and sequencing}

Two partial sequences for the cox 1 and $\operatorname{cox} 3$ genes of the P.esculenta were determined by polymerase chain reaction (PCR) using the following primer pairs: LCO1490 + HCO2198 for the fragment of cox1 gene and COIIIF + COIIIB for the fragment of cox3 gene [21].

PCR reactions were conducted in a Mastercycler gradient machine (Eppendorf AG Inc.) in a total volume of $25 \mu \mathrm{l}$, containing $18.0 \mu \mathrm{l}$ sterile distilled $\mathrm{H}_{2} \mathrm{O}, 2.5 \mu \mathrm{l} 10 \times \mathrm{LA}$ PCR buffer ( $\mathrm{Mg}^{2+}$ plus, Takara), $0.5 \mu \mathrm{l}$ dNTP $(10 \mathrm{mM}$ each, $0.2 \mathrm{mM}$ final concentration), $1 \mu \mathrm{l}$ each primer $(5 \mu \mathrm{M}), 1$ $\mu \mathrm{l}$ LA-Taq polymerase ( 1 unit, Takara), and $1 \mu \mathrm{l}$ DNA template. The thermal cycling profile was as follows: initial denaturation at $94^{\circ} \mathrm{C}$ for 2 minutes and followed by denaturation at $94^{\circ} \mathrm{C}$ for $20 \mathrm{~s}$, annealing at $52^{\circ} \mathrm{C}$ for $45 \mathrm{~s}$, and extension at $72^{\circ} \mathrm{C}$ for $1 \mathrm{~min}$, for 34 cycles. PCR products were purified using the Montage PCR Cleanup Kit (Millipore) and sequenced with ABI 3730x1 DNA Analyzer.

\section{Long PCR and sequencing by cloning and primer walking}

The mitochondrial genome of P.esculenta was amplified with a long PCR protocol. Based on the partial mitochondrial genome sequences ( $\operatorname{cox} 1$ and $\operatorname{cox} 3$ ), two pairs of 
primers: $\operatorname{cox} 1$-cox3-F (5'-AGG CTG AAC AGT CTA CCC CC-3'), $\cos 1-\cos 3-\mathrm{R}\left(5^{\prime}-\mathrm{TAA}\right.$ TCC TAC ACA TCA CTT TGG CTT TG-3'), cox3-cox 1 -F (5'-AAG CCA CTC AAC ATA CCC AAA CCT AAC C-3'), $\operatorname{cox} 3-\operatorname{cox} 1-\mathrm{R}\left(5^{\prime}\right.$-ATT GTG CTT TTC CTC ATC GTT CGT GTA G-3'), were designed to the amplification of the entire mitochondrial genome in two long PCR reactions.

PCR reactions were also done in a Mastercycler gradient machine (Eppendorf AG Inc.) and the reactions were carried out with 36 cycles of $25 \mu$ reaction volume containing $18.5 \mu \mathrm{l}$ sterile distilled $\mathrm{H}_{2} \mathrm{O}, 2.5 \mu \mathrm{l} 10 \times$ LA PCR buffer (Mg ${ }^{2+}$ plus, Takara), $0.5 \mu \mathrm{l}$ dNTP (10 mM each, $0.2 \mathrm{mM}$ final concentration), $1 \mu \mathrm{l}$ each primer $(5 \mu \mathrm{M}), 1 \mu \mathrm{l}$ LA-Taq polymerase ( 1 units, Takara), and $0.5 \mathrm{ml}$ DNA template. The thermal cycling profile was as follows: with an initial denaturation at $94^{\circ} \mathrm{C}$ for 2 minutes and followed by denaturation at $94^{\circ} \mathrm{C}$ for $20 \mathrm{~s}$, annealing at $58^{\circ} \mathrm{C}$ for $45 \mathrm{~s}$, and extension at $72^{\circ} \mathrm{C}$ for 10 minutes, for 36 cycles.

Approximately $3 \mu \mathrm{g}$ of PCR product was sheared randomly into fragments of about $1.5 \mathrm{~kb}$ by forcing it repeatedly through a narrow aperture using a Hydroshear device (Gene Machines, San Carlos, CA). Following enzymatic end repair and gel purification, these fragments were ligated into pUC18 and transformed into E.coli to create plasmid libraries using standard techniques. DNA sequence data from both strands was generated from single clones using the primer walking approach, which also conducted with ABI 3730x1 DNA Analyzer.

\section{Sequence analysis}

Base calling was performed with phred [59,60] and sequence reads were assembled in phrap with default parameters. All assembled sequences were manually checked by CONSED to remove misassemblies [61]. The locations of the 13 PCGs and two rRNAs were determined with DOGMA [46], and subsequent alignments with $C$. torquata, L. terrestris and $O$. latreillii (Annelida). The majority of tRNA genes were identified by using tRNAscan-SE 1.21 [62], employing the default search mode and the invertebrate mitochondrial genetic code for tRNA structure prediction. Remaining tRNA genes were identified by inspecting sequences for tRNA-like secondary structures and anticodons.

\section{Phylogenomic analysis}

Besides the mitochondrial genome of P.esculenta, partial or complete mitochondrial genomes from Annelida, Echiura, Pogonophora, Myzostomida, Brachiopoda, Ectoprocta, Bryozoa, and Rotifera were included in the phylogenetic analysis. Six genomes from four classes of Mollusca and four genomes from four Arthropoda major clades were also included. The root of all trees was deter- mined by using the data from Porifera, Cnidaria, and Placozoa species as the outgroup [see additional file 6].

Partial mitochondrial genome sequences of R.pachyptila (Pogonophora) and M.seymourcollegiorum (Myzostomida) contain 11 PCGs (cox1, cox2, cox3, cob, nad1, nad2, nad3, nad4, nad6, atp6 and atp8) and 10 PCGs (cox1, cox2, cox3, cob, nad4, nad4L, nad5, nad6, atp6 and atp8), respectively. In addition, atp 8 gene is missing in some mitochondrial genomes. Thus the amino acid sequences from seven shared PCGs (cox1, cox2, cox3, cob, nad4, nad6 and atp6) were aligned using Clustal $X$ with the default settings [63]. The final alignment for the 29 taxa consisted of 2,718 sites. Two phylogenetic reconstruction approaches was applied including Maximum Likelihood (ML) using PhyML 3.0 [64] and Bayesian inference analyses using MrBayes 3.1 MPI version [65].

Model selection for the amino acid dataset was done with ProtTest [66]. For a likelihood analysis, we implemented the MtArt matrix in PhyML 3.0 [64]. As the MtArt model is a very recent addition to the models commonly used [67], we could not implement it in Bayesian analysis, where we used the best scoring alternative, MtRev matrix and the gamma+invar model of evolutionary change. In the ML method, the assessment of node reliability was done using 1,000 bootstrap replicates (BPM). In the case of the Bayesian analyses, the Markov Chain Monte Carlo analyses were run for 1,000,000 generations (sampling every 100 generations) to allow adequate time for convergence. After approximate 100,000 generations, the loglikelihood values of each sampled tree had stabilized. After omitting the first 1,000 "burn in" trees, the remaining 9,000 sampled trees were used to estimate the 50\% majority rule consensus tree and the Bayesian posterior probabilities (BPP).

\section{Abbreviations}

atp6, and 8: ATPase subunits 6 and 8; bp: base pair (s); cox1-3: cytochrome c oxidase subunits I-III; PCGs: protein-coding genes; nCR: non coding region; cob: cytochrome b; mtDNA: mitochondrial DNA; nad1-6, and $4 \mathrm{~L}$ : NADH dehydrogenase subunits $1-6$ and $4 \mathrm{~L}$; $s r R N A$, and IrRNA: small and large subunits ribosomal RNA; tRNA:

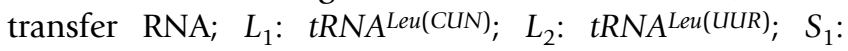

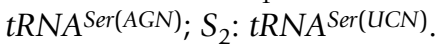

\section{Authors' contributions}

XS designed this study, performed all of the phylogenetic analyses, interpreted data and wrote the manuscript. XM and JR did the majority of the laboratory work and the primary sequence analysis. FZ was responsible for bioinformatic analyses. All authors read and approved the final manuscript. 


\section{Additional material}

\section{Additional file 1}

Genomic characteristics of six mitochondrial genomes. Genomic characteristics of the mitochondrial genomes of Phascolosoma esculenta (Sipuncula), Urechis caupo (Echiura) and four annelids (Orbinia latreillii, Clymenella torquata, Platynereis dumerilii, and Lumbricus terrestris).

Click here for file

[http://www.biomedcentral.com/content/supplementary/14712164-10-136-S1.doc]

\section{Additional file 2}

$A+C$ and $G+T$ composition along $m t$ genomes of Phascolosoma esculenta and Urechis caupo. Plot of $A+C$ and $G+T$ composition along $m t$ genomes of Phascolosoma esculenta and Urechis caupo using a sliding window of 100 nucleotides. The scaled gene maps are also presented and tRNA genes are pictured but not labelled.

Click here for file

[http://www.biomedcentral.com/content/supplementary/14712164-10-136-S2.jpeg]

\section{Additional file 3}

The base composition and skew in the mitochondrial protein-coding and ribosomal RNA genes. The AT, GC skew and AC, GT frequency in the mitochondrial protein-coding and ribosomal RNA genes of Phascolosoma esculenta (Sipuncula), Urechis caupo (Echiura) and four annelids (Orbinia latreillii, Clymenella torquata, Platynereis dumerilii, and Lumbricus terrestris).

Click here for file

[http://www.biomedcentral.com/content/supplementary/1471-

2164-10-136-S3.xls]

\section{Additional file 4}

Codon usage in 13 mitochondrial PCGs. Codon usage in 13 mitochondrial PCGs of the Phascolosoma esculenta (Sipuncula: Phascolosomatidea).

Click here for file

[http://www.biomedcentral.com/content/supplementary/14712164-10-136-S4.doc]

\section{Additional file 5}

Gene arrangements in 19 taxa. Table of gene arrangements in 19 taxa. Those matching annelids conserved gene blocks are shown in red colour. Click here for file

[http://www.biomedcentral.com/content/supplementary/14712164-10-136-S5.doc]

\section{Additional file 6}

Mitochondrial genomes used for the phylogenetic reconstruction. The list of mitochondrial genomes used for the phylogenetic reconstruction. Click here for file

[http://www.biomedcentral.com/content/supplementary/14712164-10-136-S6.doc]

\section{Acknowledgements}

The authors are grateful to Feng Jiang, Ming'an Sun, Zhenfen Chi, Lan Jiang, Fan $\mathrm{He}$, Aniza Ghazalli and Amal Mockbil for their valuable suggestions to the manuscript of this article. This study was supported by Lianyungang
Natural Science Funds (ZH200805) and Huaihai Institute of Technology Natural Science Funds (Z2008044).

\section{References}

I. Cutler EB: The Sipuncula: their systematics, biology and evolution. New York: Cornell University Press; 1994.

2. Schulze A, Cutler EB, Giribet G: Phylogeny of sipunculan worms: $A$ combined analysis of four gene regions and morphology. Mol Phylogenet Evol 2007, 42(I): I7I-192.

3. Huang DY, Chen JY, Vannier J, Saiz Salinas Jl: Early Cambrian sipunculan worms from southwest China. Proc R Soc Lond B Biol Sci 2004, 27I(1549): |67|-1676.

4. Struck TH, Schult N, Kusen T, Hickman E, Bleidorn C, McHugh D, Halanych KM: Annelid phylogeny and the status of Sipuncula and Echiura. BMC Evol Biol 2007, 7:57-67.

5. Hyman LH: The protostomatous coelomates-Phylum Sipunculida. In The Invertebrates New York: McGraw-Hill Press; 1959:610-696

6. Linnaeus C: Systema naturae per regna tria naturae, secundum classes, ordines, genera, species cum characteribus, differentiis, synonymis, locis. Editio duodecima, reformata. Holmiae; 1767.

7. Delle-Chiaje S: Memorie sulla storia e notomina degli animali senza vertebre del Regno di Napoli, Vol. I. Fratelli Fernandes. Naples, Italy 1823.

8. Quatrefages Ad: Études sur les types inférieurs de l'embranchement des Annelés. Mémoire sur l'échiure de Gaertner (Echiurus gaertnerii NOB). Ann Sci Nat Zool (Paris) 1847, 7:307-343.

9. Stephen AC: A revision of the phylum Sipuncula. Ann Mag Nat Hist 1965, 137:457-462.

10. Scheltema AH: Aplacophora as progenetic aculiferans and the coelomate origin of mollusks as the sister taxon of Sipuncula. Biol Bull 1993, I84(I):57-78

II. Guralnick RP, Lindberg DR: Reconnecting cell and animal lineages: what do cell lineages tell us about the evolution and development of Spiralia? Evolution Int J Org Evolution 200I, 55(8): $150 \mid-1519$.

12. Stephen AC, Edmonds S): The Phyla Sipuncula and Echiura. London: Trustees of the British Museum (Natural History); 1972.

13. McHugh D: Molecular evidence that echiurans and pogonophorans are derived annelids. Proc Natl Acad Sci USA 1997, 94(15):8006-8009.

14. Hessling R, Westheide W: Are Echiura derived from a segmented ancestor? Immunohistochemical analysis of the nervous system in developmental stages of Bonellia viridis. J Morphol 2002, 252(2): $100-113$

15. Meglitsch PA, Schram FR: Invertebrate Zoology. London: Oxford University Press; 1991.

16. Åkesson B: A study of the nervous system of the Sipunculoideae, with some remarks on the development of the two species Phascolion strombi Montagu and Golfingia minuta Keferstein. Unders Öresund 1958, 38: I-249.

17. Eernisse DJ, Albert JS, Anderson FE: Annelida and Arthropoda are not sister taxa: a phylogenetic analysis of spiralian metazoan morphology. Syst Biol 1992, 4 I (3):305-330.

18. Peterson KJ, Eernisse DJ: Animal phylogeny and the ancestry of bilaterians: inferences from morphology and I 8S rDNA gene sequences. Evol Dev 200I, 3(3): I70-205.

19. Nielsen C, Scharff N, Eibye-Jacobsen D: Cladistic analyses of the animal kingdom. Biol J Linn Soc Lond 1996, 57(4):385-4I0.

20. Boore JL, Brown WM: Complete sequence of the mitochondrial DNA of the annelid worm Lumbricus terrestris. Genetics 1995, I4I(I):305-319.

21. Boore JL, Macey JR, Medina M: Sequencing and comparing whole mitochondrial genomes of animals. Methods Enzymol 2005, 395:3। I-348.

22. Dellaporta SL, Xu A, Sagasser S, Jakob W, Moreno MA, Buss LW, Schierwater B: Mitochondrial genome of Trichoplax adhaerens supports placozoa as the basal lower metazoan phylum. Proc Natl Acad Sci USA 2006, I03(23):875I-8756.

23. Bayona-Bafaluy MP, Muller S, Moraes CT: Fast adaptive coevolution of nuclear and mitochondrial subunits of ATP synthetase in orangutan. Mol Biol Evol 2005, 22(3):716-724. 
24. Boore JL, Collins TM, Stanton D, Daehler LL, Brown WM: Deducing the pattern of arthropod phylogeny from mitochondrial DNA rearrangements. Nature 1995, 376(6536): 163-165.

25. Boore JL, Brown WM: Big trees from little genomes: mitochondrial gene order as a phylogenetic tool. Curr Opin Genet Dev 1998, 8(6):668-674.

26. Garey JR, Schmidt-Rhaesa A: The Essential Role of "Minor" Phyla in Molecular Studies of Animal Evolution. Amer Zool 1998, 38(6):907-917.

27. Bleidorn C, Podsiadlowski L, Bartolomaeus T: The complete mitochondrial genome of the orbiniid polychaete Orbinia latreillii (Annelida, Orbiniidae) - A novel gene order for Annelida and implications for annelid phylogeny. Gene 2006, 370:96-103.

28. Jennings RM, Halanych KM: Mitochondrial genomes of Clymenella torquata (Maldanidae) and Riftia pachyptila (Siboglinidae): evidence for conserved gene order in annelida. Mol Biol Evol 2005, 22(2):210-222.

29. Boore JL, Brown WM: Mitochondrial genomes of Galathealinum, Helobdella, and Platynereis: sequence and gene arrangement comparisons indicate that Pogonophora is not a phylum and Annelida and Arthropoda are not sister taxa. Mol Biol Evol 2000, 17(1):87-106.

30. Boore JL: Complete mitochondrial genome sequence of Urechis caupo, a representative of the phylum Echiura. BMC Genomics 2004, 5(I):67.

31. Valles Y, Boore JL: Lophotrochozoan mitochondrial genomes. Integr Comp Biol 2006, 46(4):544-557.

32. Boore JL, Staton JL: The mitochondrial genome of the Sipunculid Phascolopsis gouldii supports its association with Annelida rather than Mollusca. Mol Biol Evol 2002, I9(2): I27-137.

33. Bleidorn C, Eeckhaut I, Podsiadlowski L, Schult N, McHugh D, Halanych KM, Milinkovitch MC, Tiedemann R: Mitochondrial genome and nuclear sequence data support myzostomida as part of the annelid radiation. Mol Biol Evol 2007, 24(8):1690-1701.

34. Stechmann A, Schlegel M: Analysis of the complete mitochondrial DNA sequence of the brachiopod Terebratulina retusa places Brachiopoda within the protostomes. Proc $R$ Soc Lond $B$ Biol Sci 1999, 266( ( 433):2043-2043.

35. Noguchi $Y$, Endo K, Tajima F, Ueshima R: The mitochondrial genome of the brachiopod Laqueus rubellus. Genetics 2000, I55(I):245-259.

36. Helfenbein KG, Brown WM, Boore JL: The complete mitochondrial genome of the articulate brachiopod Terebratalia transversa. Mol Biol Evol 200I, 18(9): 1734-1744.

37. Serb JM, Lydeard C: Complete mtDNA sequence of the North American freshwater mussel, Lampsilis ornata (Unionidae): an examination of the evolution and phylogenetic utility of mitochondrial genome organization in Bivalvia (Mollusca). Mol Biol Evol 2003, 20(I I): 1854-I866.

38. Boore JL, Medina M, Rosenberg LA: Complete sequences of the highly rearranged molluscan mitochondrial genomes of the Scaphopod Graptacme eborea and the Bivalve Mytilus edulis. Mol Biol Evol 2004, 2 I (8): I 492-I 503.

39. Dreyer H, Steiner G: The complete sequences and gene organisation of the mitochondrial genomes of the heterodont bivalves Acanthocardia tuberculata and Hiatella arctica - and the first record for a putative Atpase subunit 8 gene in marine bivalves. Front Zool 2006, 3:13-26.

40. Ojala D, Montoya J, Attardi G: tRNA punctuation model of RNA processing in human mitochondria. Nature 1981, 290(5806):470-474.

4I. Shen X, Ren JF, Cui ZX, Sha ZL, Wang B, Xiang JH, Liu B: The complete mitochondrial genomes of two common shrimps (Litopenaeus vannamei and Fenneropenaeus chinensis) and their phylogenomic considerations. Gene 2007, 403(I-2):98-109.

42. Perna NT, Kocher TD: Patterns of nucleotide composition at fourfold degenerate sites of animal mitochondrial genomes. J Mol Evol 1995, 4I(3):353-358.

43. Boore JL: The complete sequence of the mitochondrial genome of Nautilus macromphalus (Mollusca: Cephalopoda). BMC Genomics 2006, 7:182.

44. Helfenbein KG, Fourcade HM, Vanjani RG, Boore JL: The mitochondrial genome of Paraspadella gotoi is highly reduced and reveals that chaetognaths are a sister group to protostomes. Proc Natl Acad Sci USA 2004, I 1 I(29): 10639-10643.
45. Medina M, Collins AG, Takaoka TL, Kuehl JV, Boore JL: Naked corals: skeleton loss in Scleractinia. Proc Natl Acad Sci USA 2006, 103(24):9096-9100.

46. Wyman SK, Jansen RK, Boore JL: Automatic annotation of organellar genomes with DOGMA. Bioinformatics 2004, 20(I7):3252-3255.

47. Staton JL: Phylogenetic analysis of the mitochondrial cytochrome c oxidase subunit I gene from I 3 sipunculan genera: Intra- and interphylum relationships. Invertebr Biol 2003, I 22(3):252.

48. Passamaneck $\mathrm{Y}$, Halanych KM: Lophotrochozoan phylogeny assessed with LSU and SSU data: evidence of lophophorate polyphyly. Mol Phylogenet Evol 2006, 40(I):20-28.

49. Kristof A, Wollesen T, Wanninger A: Segmental mode of neural patterning in sipuncula. Curr Biol 2008, I 8(I5): I I29-I I 32.

50. Blumer MJF: The larval ocelli of Golfingia misakiana (Sipuncula, Golfingiidae) and of a pelagosphera of another unidentified species. Zoomorphology 1997, I I 7(2): II5.

51. Wanninger A, Koop D, Bromham L, Noonan E, Degnan BM: Nervous and muscle system development in Phascolion strombus (Sipuncula). Dev Genes Evol 2005, 21 5( I 0):509-5I8.

52. Winnepenninckx B, Backeljau T, De Wachter R: Phylogeny of protostome worms derived from I8S rRNA sequences. Mol Biol Evol 1995, I 2(4):64 I-649.

53. Ax P: Das System der Metazoa: ein Lehrbuch der phylogenetischen Systematik. Volume 2. Stuttgart: Gustav Fischer; 1999.

54. Purschke G, Hessling R, Westheide W: The phylogenetic position of the Clitellata and the Echiura - on the problematic assessment of absent characters. J Zoolog Syst Evol Res 2000, 38(3): $165-173$.

55. Hessling R: Metameric organisation of the nervous system in developmental stages of Urechis caupo (Echiura) and its phylogenetic implications. Zoomorphology 2002, I 21 (4):22I-234.

56. Rouse GW, Fauchald K: Cladistics and polychaetes. Zoologica Scripta 1997, 26(2): 139-204.

57. Rouse GW, Fauchald K: The articulation of annelids. Zoologica Scripta 1995, 24(4):269-302.

58. Brusca RC, Brusca G]: Invertebrates. Sunderland, Mass: Sinauer Associates; 1990

59. Ewing B, Hillier L, Wendl MC, Green P: Base-calling of automated sequencer traces using phred. I. Accuracy assessment. Genome Res 1998, 8(3): 175-185.

60. Ewing B, Green P: Base-calling of automated sequencer traces using phred. II. Error probabilities. Genome Res 1998, 8(3): $186-194$

6I. Gordon D, Abajian C, Green P: Consed: a graphical tool for sequence finishing. Genome Res 1998, 8(3): 195-202.

62. Lowe TM, Eddy SR: tRNAscan-SE: a program for improved detection of transfer RNA genes in genomic sequence. Nucleic Acids Res 1997, 25(5):955-964.

63. Thompson JD, Gibson TJ, Plewniak F, Jeanmougin F, Higgins DG: The CLUSTAL $X$ windows interface: flexible strategies for multiple sequence alignment aided by quality analysis tools. Nucleic Acids Res 1997, 25(24):4876-4882.

64. Guindon S, Gascuel O: A simple, fast, and accurate algorithm to estimate large phylogenies by maximum likelihood. Syst Biol 2003, 52(5):696-704.

65. Ronquist F, Huelsenbeck JP: MrBayes 3: Bayesian phylogenetic inference under mixed models. Bioinformatics 2003, 19(12):1572-1574.

66. Abascal F, Zardoya R, Posada D: ProtTest: selection of best-fit models of protein evolution. Bioinformatics 2005, 2I(9):2104-2I05.

67. Abascal F, Posada D, Zardoya R: MtArt: a new model of amino acid replacement for Arthropoda. Mol Biol Evol 2007, 24(I): I-5. 